\title{
Prioritering i overflodens tid
}

\author{
Prioritering betyr å si nei til gode tiltak. Som leger har vi ansvar overfor den enkelte pasient, men også for \\ å jobbe for en rettferdig fordeling av ressursene.
}

Velferdsstatens bærekraft i fremtiden står og faller på dagens prioriteringer. Uansvarlig pengebruk og utnytting av jordens ressurser vil gå ut over kommende generasjoner. Gode hensikter basert på menneskers likeverd møter vanskelige avveininger, ikke bare i helsetjenesten.

Som leger har vi den enkelte pasients beste for øye. Tre prioriteringsutvalg de siste 25 år har gitt oss grunnlag for å handle med utgangspunkt i sykdommens alvorlighetsgrad, behandlingseffekt og kostnadnytte-vurderinger. I møte med den enkelte pasient kan det være vanskelig å leve opp til politikernes ønske om ansvarlig prioritering innen begrensede ressurser.

Selv om det inngår i våre etiske forpliktelser å vise sparsommelighet med offentlige midler (1), strekker vi oss nok ofte vel langt når vi gjør det beste vi formår for våre pasienter. Det kan være uttrykk for omsorgsevne, men også for feighet.

Våre kolleger i Beslutningsforum for nye metoder skal i siste instans godta eller forkaste krav om behandling under hensyntagen til prioriteringskriteriene. Et typisk eksempel er livsforlengende behandling av langtkommen kreftsykdom. Det er ikke sjelden at avslagene må forsvares i konkrete saker, for eksempel i en TV-reportasje før jul, der det var lett å føle sympati med den pasienten som sto frem og som så muligheten til livsforlengelse. Tilsvarende mente nok mange at representanten for «verdens rikeste land», som skulle begrunne avslaget, opptrådte kynisk.

Vi er ikke alene. Følgende aktuelle beskrivelse på flyktningsituasjonen kunne like godt vært brukt på prioriteringsproblemene i helsevesenet: «For det er slik folk flest er. Om einkvan er ved å drukne, spør me ikkje om vedkomande hadde gjort meir nytte for

\section{«Noen må ta de upopu- lære standpunktene»}

seg der han kom frå, om kyniske spekulanter lokka han utpå, om han har loge på alder eller bakgrunn eller høyrer til ein religion eller ein kultur eller eit miljø me misliker. Me spør heller ikkje kva redningsaksjonen vil koste. Me gjer berre det som står i vår makt for å berge vedkommende» (2).

Å være medmenneske er en god egenskap. Ofte er det også enkelt. På lengre sikt, og fra et samfunnsperspektiv, er det dessverre ikke nok. Noen må ta de upopulære standpunktene. «Alle har vi vært i situasjoner der vi har det upopulære standpunktet. Det som får andre til å riste på hodet, himle med øynene eller få en tynn strek til munn. Det er da vi viser hvem vi virkelig er. Tåler vi å stå i den pinlige stillheten eller den moralske indignasjonen det utløser?» (3).

Som leger har vi i denne sammenheng to forpliktelser: å være medmenneske og advokat for vår pasient, og å gi støtte til de av oss som har den uriasposten det er å formulere nødvendighetens kynisme. Det er en spagat det kan være lurt å øve på.

\section{Helge Schirmer \\ hekke35@hotmail.com}

Helge Schirmer (f. 1935) er pensjonert distriktslege.

Forfatter har fylt ut ICMJE-skjemaet og oppgir ingen interessekonflikter.

\section{Litteratur}

1. Etiske regler for leger § 12. http://legeforeningen. no/Om-Legeforeningen/Organisasjonen/Rad-ogutvalg/Organisasjonspolitiske-utvalg/etikk/etiskeregler-for-leger/ (27.12.2016)

2. Randen O. Medmenneske. Klassekampen 19.12.2016.

3. Tajik H. Juleevangeliet: Det farlige vitnesbyrdet. Aftenposten 21.12.2016.

Mottatt 2.1. 2017, godkjent 5.1. 2017. Redaktør: Ketil Slagstad.

Publisert først på nett. 